\title{
Critical Issues Facing School Principals
}

Ronald A. Styron, Jr., The University of Southern Mississippi, USA

Jennifer L. Styron, The University of Southern Mississippi, USA

\begin{abstract}
The purpose of this study was to further extend research initially conducted in 2003 pertaining to the critical issues K-12 principals address on a daily basis. The study involved surveying school principals within the state of Mississippi to discover the critical issues they identified, the significance level of these issues, and the rationale behind the top ranked critical issue as identified by each principal. Findings indicated several changes in rank order of the issues, but accountability was once again noted as the most critical issue. A chi-square and Cramer's V treatments suggested no statistically significant relationship between the independent variables, gender, age, school level, administrative experience, education system and highest degree, and the dependent variable, critical issue. Moreover, data indicated school safety was considered less critical than several other issues.
\end{abstract}

Keywords: leadership; accountability; principalship

\section{INTRODUCTION}

\section{Accountability}

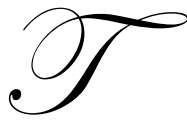

he concept of accountability is not new. It has been a part of the educational psyche in the United States since the launch of Sputnik, the first earth orbiting satellite, by Russia in 1957 . This event sparked a revolution of science education driven by citizenry paranoia over the possibility of Russia spying on the country from outer space (Abramson, 2007). The next significant event was the passage of the Elementary and Secondary Education Act (ESEA) under the President Lyndon Johnson administration in 1965. This act contained verbiage relative to accountability and high standards (United States Department of Education).

In 1983, A Nation At-Risk was published by Terence Bell, a member of the National Commission on Excellence in Education. This report included assessment of US schools and colleges and included recommendations intended to improve education (Gratch, 1993). The information contained in the report was interpreted as a scathing indictment of the American educational system that led to great upheaval and change (Jensen \& Kiley, 2000). In 1989, President George Bush brought the nation's governors together for the first national summit on education. This event represented the first time in the country's history where national educational goals were created. The goals directed schools to begin programs that would ensure every kindergartener would begin school read to learn, the graduation rate would increase to $90 \%, 4^{\text {th }}, 8^{\text {th }}$, and $12^{\text {th }}$ grade students would master five core subject before graduation, students would become global leaders in math and science, adult literacy and workforce preparedness, and safe and drug-free schools (Vinovskis, 1999). In 1994, Goals 2000: Educate America Act was signed into law. This Act supported State efforts to develop clear and rigorous standards for what every child should know and be able to do. It also provided resources to communities and states to ensure that all students would reach national goals (H.R. 1804).

The current iteration of accountability, the No Child Left Behind Act (NCLB) was approved by congress in 2002. This Act required each state to develop a system of accountability including annual assessments. It also required teachers to meet "highly qualified" status thus indicating full state certification to teach assigned subject areas. One of the most signification portions of the Act included a mandate for each school to achieve Adequate Yearly Progress (AYP). Student populations were divided into subgroups including Economically disadvantaged; Special education; Limited English Proficient students (also known as ELL---English Language Learners); and those from major racial/ethnic groups. Schools that contained subgroups who did not achieve AYP would receive 
substantial sanctions that could include redistricting of students, termination of teachers and administrators, and in the most severe cases, school closing (United States Department of Education, 2001; Petterway, Kritsonis, \& Herrington, 2006).

\section{Mississippi Accountability}

Public schools in the State of Mississippi are currently mandated to administer the Mississippi Curriculum Test second edition (MCT2). This test is designed to meet the federal mandates of NCLB and assesses reading, language arts, math and science. Test questions are of different ranges of difficulty as measured by Normal Webb's learning process called Depth of Knowledge (DOK) (Webb \& Hess, 2005). The MCT2 is administered in grades 3-8 over a three-day period. The results of these assessments are used to determine achievement levels labeled basic, proficient or advanced (Mississippi Department of Education, 2009).

\section{Accountability And School Principals}

Although accountability has been a part of the American educational system, until NCLB there were few consequences for principals if their students were low performing. For many years the focus of federal, state and local efforts was on issues pertaining to equity of access and funding. NCLB was the manifestation of a new focus for education, a focus on issues of adequacy. School districts had to determine if their students receiving an adequate education (Odden \& Picus, 2008).

NCLB legislation created a more stressful, test-driven environment for school principals as there were dire consequences for low student performance. The termination of principals and resulting community and professional embarrassment has created a climate of constant stress and pressure on them. These pressures were exacerbated at low-achieving schools as principals were under great pressure to not only achieve AYP gains, but substantial gains to get school scores on a par with other schools. Schools, that because of reasons beyond the control of the principal such as economic factors, may not have had the same level of difficulty in achieving academic gains (Hanushek, 2002). Ironically, NCLB has few provisions addressing the role of principals in school improvement. This lack of ownership has contributed to a feeling of helplessness as many feel part of a system where they have no meaningful input (Sunderman, Orfield \& James, 2006; Carlin, 2010).

Another factor serving as a stressor for school principals has to do with the standardized tests that are mandated by legislation to be used to determine school performance scores and measure student achievement. There are questions regarding the negative implications of curriculum attributed to accountability programming. According to Kesidou and Roseman (2002), accountability programming may be influencing curriculum to focus on the collection of superficial fact-based concepts. Concurrently, as we move into the $21^{\text {st }}$ century, it is becoming increasingly important for students to be able to problem solve, develop critical thinking skills, and analyze information (Wagner, 2008). Accountability programming may in fact discourage teachers from promoting the types of pedagogy, such as differentiated instruction, that develop knowledge transfer (Wiggins \& McTighe, 2005) and other meaningful types of long-lasting learning (Schoen \& Fusarelli, 2008). Pressure from accountability has also manifested itself in an increase in student cheating. Students are feeling pressure to perform at acceptable levels on standardized tests are (Anderman \& Murdock, 2006). This phenomenon has created another stressor for principals as many accuse them of looking the other way when teachers report student cheating (Lanthrop \& Foss, 2005).

\section{METHODOLOGY}

This study explored the critical issues principals within the state of Mississippi currently face as compared to those issues identified in 2003 (Styron, Roberson, Schweinle \& Lee, 2005). The severity of each issue, using a sample survey technique, was determined by self-determined ranking with a rationale pertaining to the most significant issue described in paragraph form (Gay \& Airasian, 2003). Investigators deployed a questionnaire developed specifically for this study (see Attachment A). The questionnaires consisted of six closed form items for collection of demographic data and two open-ended questions. Research data gathered from the previous study conducted in 2003 was utilized to cross examine whether or not the same critical issues currently challenge K-12 principals and if the significance of those issues has changed over the last 7 years. The research team distributed 200 
questionnaires using mailing addresses provided by the Mississippi Department of Education, 50 were returned for a return rate of $25 \%$.

Due to a variety of verbatim responses, researchers used a selective coding technique to develop topical categories for each qualitative response set and a nominal ordinal method recording the relative frequency for each response category to quantify responses (Trochim, 2006). Data was collected, transcribed and coded to determine if any themes existed, thus providing insight to the phenomenon surrounding self-identified issues. The themes identified through this process included accountability, discipline, external support, funding, parents, plant operations, safety, special education, staffing and time. Data was analyzed using SPSS. Contingency tables (crosstabs) were created and a chi-square analysis was conducted to determine whether the individual variables of gender, age, school level, administrative experience, education system or highest degree obtained were statistically independent of reported critical issues.

\section{DATA}

As indicated in Table 1, regardless of gender, accountability was the most frequently reported response and safety was the least frequent response.

Table 1: Highest Ranking Critical Issue by Gender

\begin{tabular}{|l|c|c|c|}
\hline Critical issues in rank order & Male & Female & \% \\
\hline Accountability & 10 & 9 & 43.2 \\
\hline Staffing & 1 & 3 & 9.1 \\
\hline Discipline & 1 & 3 & 9.1 \\
\hline Time & 0 & 2 & 4.5 \\
\hline Funding & 5 & 5 & 2.7 \\
\hline External Support & 1 & 0 & 2.3 \\
\hline Parents & 1 & 0 & 2.3 \\
\hline Safety & 0 & 1 & 2.3 \\
\hline SPED & 1 & 0 & 2.3 \\
\hline Plan Operations & 1 & 0 & 2.3 \\
\hline & & & \\
\hline Total (n=44) & 21 & 23 & \\
\hline
\end{tabular}

As indicated in Table 2, regardless of age, accountability was the most frequently reported response and safety was the least frequent response.

Table 2: Highest Ranking Critical Issue by Age

\begin{tabular}{|l|c|c|c|c|c|c|}
\hline Critical issues in rank order & $\mathbf{2 6 - 3 0}$ & $\mathbf{3 1 - 3 5}$ & $\mathbf{3 6 - 3 9}$ & $\mathbf{4 0 +}$ & Unidentified & \% \\
\hline Accountability & 0 & 2 & 3 & 17 & 0 & 44 \\
\hline Staffing & & 0 & 0 & 4 & 0 & 8 \\
\hline Discipline & 1 & 0 & 0 & 5 & 0 & 12 \\
\hline Time & 0 & 0 & 0 & 3 & 0 & 6 \\
\hline Funding & 0 & 2 & 0 & 8 & 0 & 20 \\
\hline External Support & 0 & 0 & 0 & 1 & 0 & 2 \\
\hline Parents & 0 & 0 & 1 & 0 & 0 & 2 \\
\hline Safety & 0 & 0 & 0 & 0 & 1 & 2 \\
\hline SPED & 0 & 0 & 0 & 1 & 0 & 2 \\
\hline Plan Operations & 0 & 0 & 1 & 0 & 0 & 2 \\
\hline Total (n=50) & 1 & 4 & 5 & 39 & 1 & \\
\hline
\end{tabular}

As indicated in Table 3, regardless of school level, accountability was the most frequently reported response and safety was the least frequent response. 
Table 3: Highest Ranking Critical Issue by School Level of Administrator

\begin{tabular}{|l|c|c|c|c|c|}
\hline Critical issues in rank order & Elementary & Middle & Junior & High & \% \\
\hline Accountability & 7 & 4 & 1 & 10 & 44 \\
\hline Staffing & 2 & 1 & 0 & 1 & 8 \\
\hline Discipline & 3 & 1 & 0 & 2 & 12 \\
\hline Time & 3 & 0 & 0 & 0 & 6 \\
\hline Funding & 3 & 3 & 0 & 4 & 20 \\
\hline External Support & 0 & 0 & 0 & 0 & 2 \\
\hline Parents & 0 & 1 & 0 & 0 & 2 \\
\hline Safety & 0 & 0 & 0 & 1 & 2 \\
\hline SPED & 0 & 0 & 0 & & 2 \\
\hline Plant Operations & 1 & 0 & 0 & & 0 \\
\hline Total (n=50) & 19 & 10 & 1 & 20 & 2 \\
\hline
\end{tabular}

As indicated in Table 4, regardless of years of administrative experience, accountability was the most frequently reported response and safety was the least frequent response.

Table 4: Highest Ranking Critical Issue by Administrative Experience

\begin{tabular}{|c|c|c|c|c|c|}
\hline Critical issues in rank order & $1-4$ years & $5-8$ years & 9-12 years & 13+ years & $\%$ \\
\hline Accountability & 5 & 4 & 7 & 6 & 44 \\
\hline Staffing & 2 & 1 & 0 & 1 & 8 \\
\hline Discipline & 0 & 2 & 2 & 2 & 12 \\
\hline Time & 0 & 0 & 1 & 2 & 6 \\
\hline Funding & 1 & 2 & 2 & 5 & 20 \\
\hline External Support & 0 & 0 & 0 & 1 & 2 \\
\hline Parents & 1 & 0 & 0 & 0 & 2 \\
\hline Safety & 1 & 0 & 0 & 0 & 2 \\
\hline SPED & 0 & 0 & 0 & 1 & 2 \\
\hline Plant Operations & 0 & 1 & 0 & 0 & 2 \\
\hline Total $(n=50)$ & 10 & 10 & 12 & 18 & \\
\hline
\end{tabular}

As indicated in Table 5, regardless of school type, accountability was the most frequently reported response and safety was the least frequent response.

Table 5: Highest Ranking Critical Issue by Education System

\begin{tabular}{|l|c|c|c|c|c|}
\hline Critical issues in rank order & Public & Private & Parochial & Hospital & \% \\
\hline Accountability & 22 & 0 & 0 & 0 & 44 \\
\hline Staffing & 4 & 0 & 0 & 0 & 8 \\
\hline Discipline & 5 & 0 & 0 & 1 & 12 \\
\hline Time & 3 & 0 & 0 & 0 & 6 \\
\hline Funding & 10 & 0 & 0 & 0 & 20 \\
\hline External Support & 1 & 0 & 0 & 0 & 2 \\
\hline Parents & 1 & 0 & 0 & 0 & 2 \\
\hline Safety & 1 & 0 & 0 & 0 & 2 \\
\hline SPED & 1 & 0 & 0 & 0 & 0 \\
\hline Plant Operations & 1 & 0 & 0 & & 0 \\
\hline Total (n=50) & 49 & 0 & 0 & & 0 \\
\hline
\end{tabular}

As indicated in Table 6, regardless of degree level, accountability was the most frequently reported response and safety was the least frequent response. 
Table 6: Highest Ranking Critical Issue by Highest Degree Level

\begin{tabular}{|l|c|c|c|c|}
\hline Critical issues in rank order & Masters & Specialist & PhD & \% \\
\hline Accountability & 10 & 6 & 5 & 42.9 \\
\hline Staffing & 2 & 2 & 0 & 8.2 \\
\hline Discipline & 4 & 0 & 2 & 12.2 \\
\hline Time & 2 & 0 & 2 & 6.1 \\
\hline Funding & 5 & 3 & 0 & 20.4 \\
\hline External Support & 1 & 0 & 0 & 2 \\
\hline Parents & 1 & 0 & 1 & 2 \\
\hline Safety & 0 & 0 & 1 & 2 \\
\hline SPED & 0 & 0 & 0 & 2 \\
\hline Plant Operations & 0 & 1 & & \\
\hline Total (n=49) & 26 & 12 & & 2 \\
\hline
\end{tabular}

As indicated in Figure 1, in 2003 accountability was the most frequent reported response and with the exception of plant, safety was the least reported response.

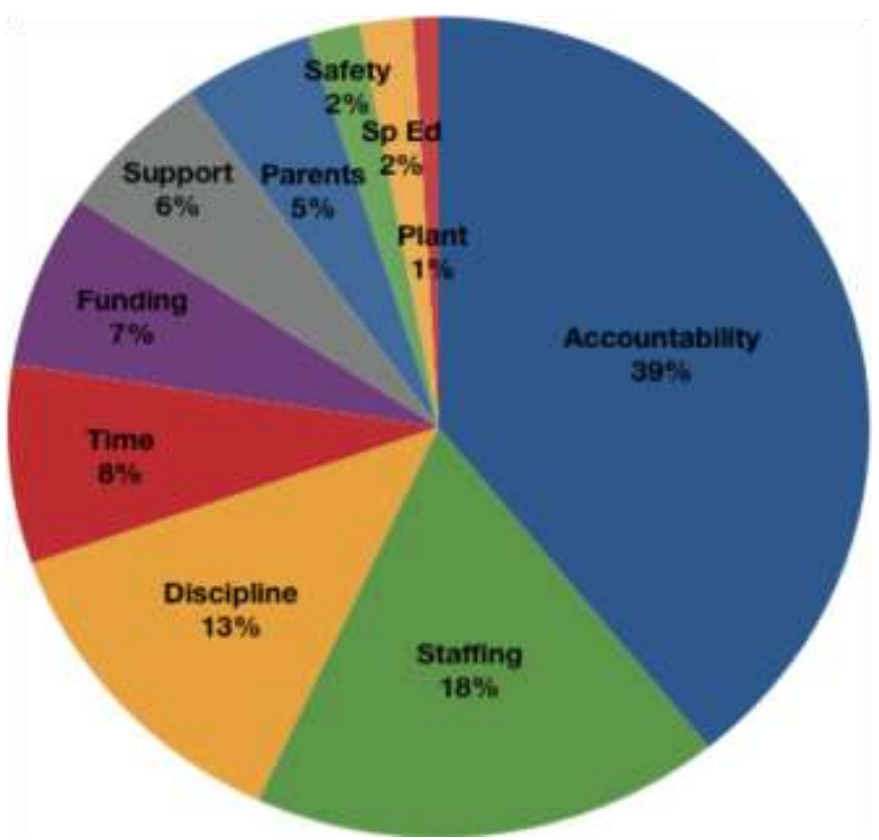

Figure 1: Critical Issues Reported by Administrators in 2003

As indicated in Figure 2, in 2010, accountability was the most frequently reported response and safety, tied with plant, special ed, parents and support, was the least frequent response. 


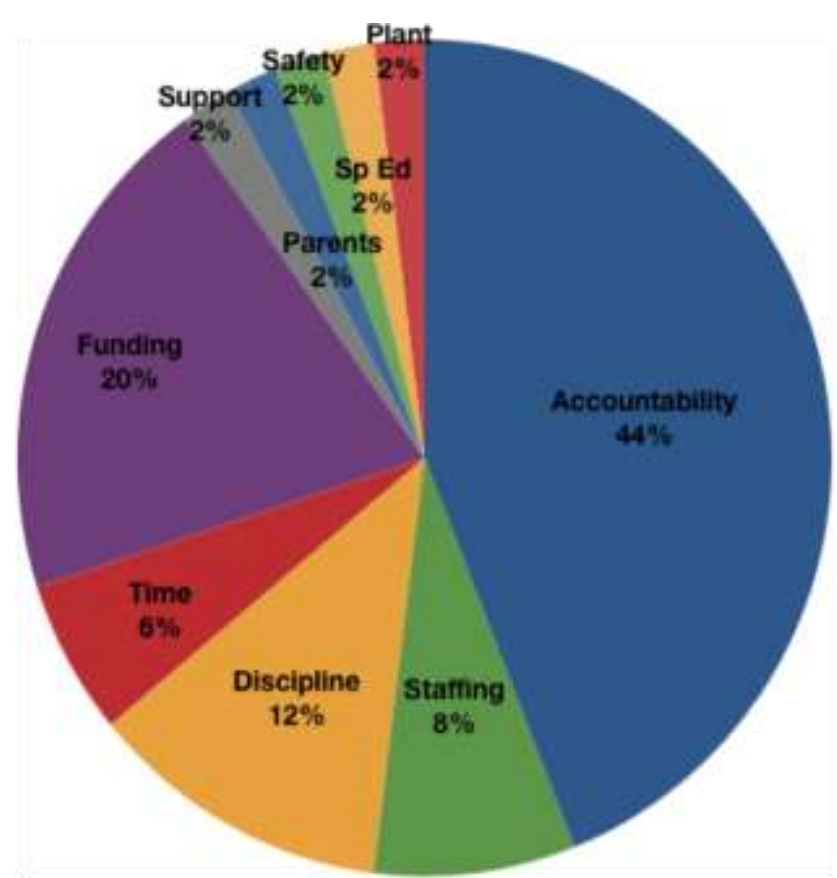

Figure 2: Critical Issues Reported by Administrators in 2010

As indicated in Table 7, responses for funding, staffing and time increased from 2003 to 2010.

Table 7: Response Change

\begin{tabular}{|l|c|c|c|c|}
\hline \multicolumn{1}{|c|}{ Rank } & $\mathbf{2 0 0 3}$ & $\mathbf{\%}$ & $\mathbf{2 0 1 0}$ & $\mathbf{\%}$ \\
\hline$\# 1$ & Accountability & 39 & Accountability & 44 \\
\hline$\# 2$ & Staffing & 38 & Funding & 20 \\
\hline$\# 3$ & Discipline & 13 & Discipline & 12 \\
\hline$\# 4$ & Time & 8 & Staffing & 8 \\
\hline$\# 5$ & Funding & 7 & Time & 6 \\
\hline$\# 6$ & Support & 6 & Plant Operations & 2 \\
\hline$\# 7$ & Parents & 2 & Parents & 2 \\
\hline$\# 8$ & Safety & 2 & Safety & 2 \\
\hline$\# 9$ & SPED & 2 & SPED & 2 \\
\hline$\# 10$ & Plan Operations & 1 & Support & 2 \\
\hline
\end{tabular}

\section{DISCUSSION}

Data suggested that principals regarded issues dealing with accountability as the most critical issue of which they dealt. These findings are consistent with research regarding experiences by school principals regarding accountability (Sunderman, Orfield \& James, 2006; Anderman \& Murdock, 2006; Carlin, F, 2010; Schoen \& Fusarelli, 2010). Furthermore, both the chi-square and Cramer's V treatments were not statistically significant thus concluding that no statistically significant relationship between the independent variables and the dependent variable, critical issue. This indicated that principals, regardless of their gender, age, school level, administrative experience, education system, or highest degree all viewed accountability as their most critical issue school issue.

Findings also suggested a disturbing trend regarding attention given by principals to school safety. As documented in this research, principals viewed safety as one of the least critical issues of which they are concerned with several other issues rated higher in terms of importance. The researchers question if the relatively low value assigned to the importance of school safety has been influenced by the preoccupation of principals on matters 
dealing with the issue rated highest, those dealing with accountability (Lashway, 2002; Bucher \& Manning 2005; Horng, Klasik \& Loeb, 2009).

It should also be noted that issues dealing with funding are now seen as second most critical, ranked only behind accountability. This ranking may reflect current difficult economic conditions. Since Mississippi ranks $50^{\text {th }}$ in per capita income among states, it is no surprise that students in the state are some of the most underserved in the United States (Southern Education Foundation, 2009). Mississippi also has a current unemployment rate of 9.8\% (Mississippi Business Journal, 2010). This may also suggest that, as perceived by principals, economic conditions have deteriorated since 2003. Since there have been numerous research studies documenting the dreadful effects of a poor economy on student achievement, it may be no surprise that principals have moved this issue to a higher level of concern (Hanushek, 2002).

\section{RECOMMENDATIONS FOR FUTURE RESEARCH}

\section{School Safety, Accountability And School Principals}

The researchers would have felt negligent in their discussion of the study without drawing attention to findings that indicate accountability issues as most critical, while also ranking school safety issues almost last in their priorities. School principals are expected today to possess a sophisticated set of skills to be able to address everything from school safety to accountability (Lashway, 2002). There is no more important administrative task than establishing a climate of school safety (Bucher \& Manning 2005). But with so many expectations of the position, when prioritizing their day and allocating their time, because of the ominous penalties associated with accountability failures, might principals be addressing accountability at the expense of school safety matters (Horng, Klasik \& Loeb, 2009)? The researchers propose future studies to help determine if a focus on accountability impacts the ability of principals to address issues connected to school safety (i.e. bullying, violent acts, possession of weapons, substance abuse, etc.).

Additional recommendations for future research include a) replication of the study throughout the United States to see if similar critical issues are present and to be able to address them accordingly; b) research pertaining to specific accountability factors connected to school principal critical issues to flesh out details; and c) teacher, parent and, where appropriate, student research pertaining to the issues they consider most critical to identify similarities and differences.

\section{CONCLUSION}

This study was conducted to determine the most critical issues of which school principals now face and if those critical issues have changed during the past several years. It was the intent of the researchers to provide data that could help inform K-12 policy, school-level administrative practice, and higher education curricular decisions and priorities in principal preparation programs.

\section{AUTHOR INFORMATION}

Dr. Ronald Styron is currently Director of the University of Southern Mississippi Gulf Coast Instructional Leadership Center. He has received numerous awards including Principal of the Year and Louisiana PTA Educator of Distinction. Dr. Styron is a fellow for the Greater New Orleans School Leadership Center and served 6 six years as a regional facilitator for the Louisiana Principal Internship Program. He has administered several grants throughout his career totaling and has a proven record of publications and presentations based on his research interests of school leadership and educational applications of technology.

Jennifer Styron is a Research Specialist in the Center for Research, Evaluation, Assessment, and Training Services at The University of Southern Mississippi. Her previous experiences include monitoring and revamping Distance Education programming; coordinating marketing projects for online learning; guiding administrators and faculty in the design and development of distance education courses; and providing professional development for K-12 school leaders centered on experiential learning and reflective practice. 


\section{REFERENCES}

1. Abramson, L. (2007). Sputnik Left Legacy for U.S. Science Education. NPR reports. Retrieved October 29, 2010 from http://www.npr.org/templates/story/story.php?storyId=14829195.

2. Anderman, M. A. \& Murdock, T. B. (2007). Psychology of Academic Cheating, Elsevier Press, Burlington: MA.

3. Bucher, K. .T. \& Manning, M. L. (2005). Creating safe schools, Journal of Educational Strategies, Issues and Ideas, 79(1), 55-60.

4. Carlin, W. F. (2010). A qualitative study of the perceived stress levels of principals in the No Child Left Behind era. Dissertation retrieved from ProQuest Dissertations and Theses on October 22, 2010 from http://gradworks.umi/com/34/08/3408700.html.

5. Gay, L. R. \& Airasian, P. (2003). Educational research: Competencies for analysis and application $7^{\text {th }}$ Edition. Upper Saddle River, NJ: Pearson Education.

6. Gratch, B. G. 1993. Five Years After A Nation at Risk: An Annotated Bibliography, Reference Services Review, (17)4, 29-48.

7. Hanushek, E. A. (2002). Publicly provided education, Handbook of Public Economics, 4, 2045-2141.

8. Horng, E. L., Klasik, D., \& Loeb, S. (2009). Principal time-use and school effectiveness. (School Leadership Research Report No. 09-3). Stanford, CA: Stanford University, Institute for Research on Education Policy \& Practice.

9. H. R. 1804, Goals 2000: Education America Act. Retrieved on October 29, 2010 from http://www2.ed.gov/legislation/GOALS2000/TheAct/index.html.

10. Jensen, R.A. \& Kiley T.J. (2000). Teaching, Leading, and Learning: Becoming Caring Professionals. Houghton Mifflin Company, Boston: MA.

11. Kesidou S, \& Roseman J. E. (2002). How well do middle school science programs measure up? Findings from Project 2061's curriculum review. Journal of Research in Science Teaching 39:522-549.

12. Lanthrop, A. \& Foss, K. 2005. Guiding students from cheating and plagiarism to honesty and integrity. Libraries Unlimited, Westport: CT.

13. Lashway, L. (2002). Trends in school leadership. Eugene, OR: ERIC Clearinghouse on Educational Management.

14. Mississippi Department of Education (2009). Office of Student Assessment. Retrieved October 6, 2010, from http://www.mde.k12.ms.us/acad/osa/mct2/.

15. Mississippi Unemployment Report (2010). Mississippi Business Journal, retrieved October 26, from http://msbusiness.com/blog/2010/09/august-unemployment-2010/.

16. Odden, A., \& Picus, L., (2008). School Finance, A Policy Perspective. $4^{\text {th }}$ edition, McGraw Hill, Columbus: $\mathrm{OH}$.

17. Petterway, A., Kritsonis, W., \& Herrington, D. (2006). The impact of high stakes testing on academic achievement of English language learners in Texas public education: National implications. Dissertation, Lamar University.

18. Schoen. L. \& Fusarelli, L. D. (2008). Innovation, NCLB, and the fear factor, Educational Policy, 22(1), 181-203.

19. Southern Education Foundation (2009). Economic Report, Southern Region retrieved October 25, 2010 from http://www.southerneducation.org/.

20. Styron, R. A., Roberson, T., Schweinle, W., \& Lee, D. E. (2005). I'm fighting a lion with a toothpick: The No Child Left Behind Act from the perspective of K-12 principals. The Researcher, 19, 6-11.

21. Sunderman, G. L., Orfield, G. K., \& James S. (2006). Flawed assumptions: How No Child Left Behind fails principals, Principal Leadership, 6(8) 16-19.

22. Trochim, W. M. (2006). The research methods knowledge base, $2^{\text {nd }}$ edition, retrieved October 24,2010 from http://www.socialresearchmethods.net/kb.

23. Vinovskis, M. (1999). The Road to Charlottesville: The 1989 Education Summit. Institute for Social Research and School for Public Policy at University of Michigan, Department of History.

24. U.S. Department of Education Index of Legislation Directory. The Elementary and Secondary Education Act, retrieved October 29, 2010 from http:www.ed.gov/legislation/.

25. U.S. Department of Education. (2001). No Child Left Behind Act. § 115. Stat. 1425 - 2094. Retrieved October 30, 2010 from http://www2.ed.gov/policy/elsec/guid/states/index.html. 
26. Wagner, T. (2008). The Global Achievement Gap: Why Even Our Best Schools Don't Teach the New Survival Skills Our Children Need-And What We Can Do About It. New York: Basic Books.

27. Webb, N. \& Hess, K. (2005). Alignment, Depth of Knowledge \& Change. Wisconsin Center for Education Research. Retrieved October 26, 2010 from http://facstaff.wcer.wisc.edu/normw/.

28. Wiggins G. P. \& McTighe, J. 2005. Understanding by Design. Association for Supervision and Curriculum Development, Alexandria: VA. 


\section{APPENDIX A}

\section{Critical Issues Facing School Principals}

This survey is being conducted to ascertain the views of principals relevant to the critical issues they now face. Participation is completely voluntary and may be discontinued at any time without penalty. By completing and returning this questionnaire, you are indicating your consent to participate in the study. Responses will be anonymous. Your cooperation is greatly appreciated.

Directions: Please circle your response

1. Gender: Male Female

2. Age: $22-25 \quad 26-30 \quad 31-35 \quad 36-40 \quad 40$ or older

3. What grade level is your school? Elementary Middle Junior

4. How many years have you been in education as an administrator?
Less than 1
$1-4$
$5-8$
$9-12$
13 or over

5. In which system are you currently employed?

Public Private (non-parochial) Parochial

6. Highest Degree obtained: $\quad$ Bachelor Master Specialist PhD/EdD

7. What are the most critical issues impacting your principalship? Please list and rank in order of importance from most significant (1) to least significant (10).

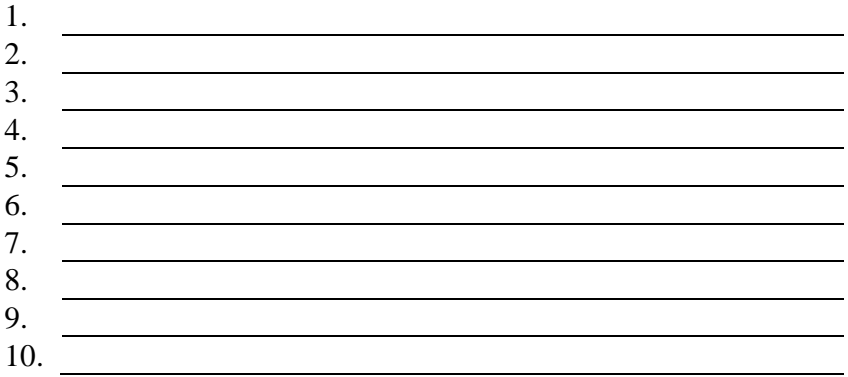

8. In three paragraphs or less, please state your rationale for the issue you consider most critical on the rear of this form. 